\title{
Analysis of AISI D2 Steel by using SEM Images
}

\author{
Shambhu P. Choubisa, Abhishek Sharma, Himanshu Pandya
}

\begin{abstract}
Hard turning is a new emerging technique in manufacturing industry which involves turning of hard steel having hardness more than $60 \mathrm{HRC}$. Here in the present work, the objective of the study is steel type ENX160CrMo having hardness 62 HRC. Hard turning were carried out at different cutting parameters and chip hardness and micro- chip SEM images were observed. Micro- machined surface images, observed at different cutting condition to know the relation between chip morphology and micro-structure of the machined surface. White layer formation indicates the reduction in fatigue life was also studied.
\end{abstract}

Keywords: Hard turning; Chip formation; AISI D2 steel; White layer; Micro structure of machined surface.

\section{INTRODUCTION}

The machining of hardened steel is a widely used metal removal method that produces high precision parts for the aerospace industry. Today, hard turning has replaced the grinding processes of hardened steel components in practice. Hard steel provides greater wear resistance and durability, making it suitable to heavy - duty applications. Hard steel is used to make metal objects that are subjected to high levels of force or abuse. For example, most automotive parts are made from this material, particularly those used for trucking, and in aerospace industries. The machining of the hardened steels can be achieved using super-hard cutting tool materials such as cubic boron nitride (CBN) tools and improved ceramic tools. One of the main benefits is that these advanced tools allow operating on hardened materials without coolants. From an economical point of view, hard turning (hard machining) is most cost effective than grinding and it reduces set-up and machining costs. Moreover, it does not require use of any coolants. The time for machining is narrowed down as high as 60 percent for turning hard materials when compared to the grinding process. Although $\mathrm{CBN}$, Ceramic tools can offer advantages in terms of machining of hardened materials (difficult to machine materials), reduced machining time, and the physical effect of cutting conditions is still not clearly understood when machining hardened materials.

Revised Manuscript Received on March 5, 2020.

Shambhu P. Choubisa*, Techno India NJR Institute of Technology Udaipur

choubisa.shambhu@gmail.com*

Abhishek Sharma, Techno India NJR Institute of Technology Udaipur Himanshu Pandya, Techno India NJR Institute of Technology Udaipur
In the conventional machining of low hardness materials, the strain rate usually reaches from 103 to $106 \mathrm{~s}^{-1}$ and strain frequently reaches up to 4 . The temperature in the material's primary deformation zone usually ranges from $200^{\circ} \mathrm{C}$ to $400^{\circ} \mathrm{C}$ and at the tool-chip interface temperature reaches $1000^{\circ} \mathrm{C}$ depending on surface firmness of work material and cutting speed. For instance, at the cutting speed of 320 $\mathrm{m} / \mathrm{min}$, the cutting tool-chip boundary temperature is roughly $410{ }^{\circ} \mathrm{C}$ for an aluminum alloy (Brinell hardness) (BH 100), $750{ }^{\circ} \mathrm{C}$ for brittle gray cast iron (BH 200), and over $1000^{\circ} \mathrm{C}$ with a mild steel (BH 200)

In hard turning the temperature is even higher and it keeps increasing with the increase in hardness of the material. The heat distribution in formation of chip, and work piece surface depends on the cutting conditions, cutting tool and environmental conditions

\section{MATERIALS SELECTION}

The work piece under the consideration is high alloyed steel (type ENX160CrMoV12/AISI D2). For the manufacturing of moulds, stamps used in presses, deep drawing dies, and other tools, this steel is usually used. Overall hardness is about 62 HRC. The chemical composition and thermo mechanical properties are given in the Tables 1 and 2 respectively.

Table 1. AISI D2 steel constituents, wt\%. (Source: Steel heat treatment book)

\begin{tabular}{|r|l|l|l|l|l|l|l|l|l|}
\hline $\mathrm{C}$ & $\mathrm{Si}$ & $\mathrm{Mn}$ & $\mathrm{P}$ & $\mathrm{S}$ & $\mathrm{Cr}$ & $\mathrm{Mo}$ & $\mathrm{V}$ & $\mathrm{W}$ & $\mathrm{Fe}$ \\
\hline 1.58 & .26 & .32 & .01 & .01 & 12 & .16 & .4 & .01 & 85.25 \\
\hline
\end{tabular}

Table 2. Mechanical and thermal properties at ambient conditions. (Source: Steel heat treatment book)

\begin{tabular}{|c|c|c|c|}
\hline \multirow[b]{2}{*}{$\begin{array}{l}\text { UTS, } \\
\text { (Mpa) }\end{array}$} & \multicolumn{2}{|c|}{ Hardness , (HRC) } & \multirow[b]{2}{*}{$\begin{array}{l}\text { Thermal } \\
\text { Conductivity } \\
\left(\mathrm{w} \mathrm{m}^{-1} \mathrm{c}^{-1}\right)\end{array}$} \\
\hline & $\begin{array}{l}\text { Annealing } \\
\text { state }\end{array}$ & $\begin{array}{l}\text { Quenched } \\
\text { state }\end{array}$ & \\
\hline 720 & 23 & 62 & 20 \\
\hline
\end{tabular}

\subsection{Cutting tool}

Hard turning involves special and improved cutting tools for machining which can resist high temperature, hardness and which can also enhance surface quality. Cutting tool insert for hard turning requires special tool holders, improved machinery, and they are also not easily available. Sintered carbide tungsten cutting tools are very elation immune and can easily bear excess temperatures than standard high speed steel tools. 
Cemented carbide is a composite where tungsten carbide particles are the accumulated and the cobalt works as the matrix. Tools of carbide can bear higher temperatures without wear while perform machining easily on work pieces like mild steel, cast iron and hard materials but carbide tools are extremely favorable in such conditions. They can also be used for higher time period and they maintain their edges sharp and providing good surface finish.

Hence in the present work sintered tungsten carbide tool is selected for hard turning. Three cutting tools are selected with three nose radii's i.e. $2 \mathrm{~mm}, 3 \mathrm{~mm}, 5 \mathrm{~mm}$. Table 3 shows the physical properties of cutting tool.

The present work is based on observation of machined surface, sub- surface images, chip images. The complete study consist of observing the micro images of chips, machined surface images on SEM and micro hardness of chips.

The Table 3 show the various properties like (E)Young's modulus, Modulus of Rigidity $(\mathrm{G})$, bulk modulus(K), hardness, Tensile strength, Compressive strength. Table 4 shows the selected cutting parameters.

Table 3. Properties of cutting tool.

\begin{tabular}{|l|l|l|}
\hline $\begin{array}{l}\text { Feed } \\
(\mathrm{mm} / \text { rev })\end{array}$ & $\begin{array}{l}\text { Cutting } \\
\text { speed(m/min) }\end{array}$ & $\begin{array}{l}\text { Depth } \\
(\mathrm{mm})\end{array}$ \\
\hline 0.05 & 55 & 0.15 \\
\hline 0.1 & 94 & 0.25 \\
\hline 0.15 & 157 & 0.75 \\
\hline
\end{tabular}

Table 4. Cutting parameters

\begin{tabular}{|l|l|l|l|l|l|}
\hline & & & & & \\
E & K & G & Hardness(HRC) & $\begin{array}{l}\text { Com } \\
\text { pres } \\
\text { sive } \\
\text { Ttrensile } \\
\text { strength } \\
\text { ngth }\end{array}$ \\
\hline $\begin{array}{l}530- \\
700\end{array}$ & $\mathbf{6 3 0 - 6 5}$ & & & & \\
GPa & GPa & GPa & 88 & 344 & 2.7 \\
\hline
\end{tabular}

2.2 Study involves chip morphology and machined microstructure: -In this part of experiments the objective was to study about chip morphology, micro hardness variation and micro-structure of machined surface. The parameters selected for chip morphology and micro-hardness test are shown in Table 4. The parameters selected for machined microstructure are shown in Table 5, Table 6, Table 7 and Table 8, Table 9, Table 10.

Table 5. Feed parameters for the study of micro images of chips and chip hardness.

Table 6. Speed parameters for the study of micro images of chips and chip hardness.

\begin{tabular}{|l|l|l|l|}
\hline $\begin{array}{l}\text { Nose } \\
\text { radius(mm) }\end{array}$ & $\begin{array}{l}\text { Depth } \\
(\mathbf{m m})\end{array}$ & $\begin{array}{l}\text { Feed } \\
(\mathbf{m m} / \mathbf{r e v})\end{array}$ & $\begin{array}{l}\text { Speed } \\
(\mathbf{m} / \mathbf{m i n})\end{array}$ \\
\hline & & & 55 \\
\cline { 3 - 3 } 2 & 1 & .1 & 94 \\
\cline { 3 - 4 } & & & 157 \\
\cline { 2 - 3 } & & & 263 \\
\hline
\end{tabular}

Table7. Speed parameters for the study of micro images of machined surface.

\begin{tabular}{|c|c|c|c|}
\hline $\begin{array}{l}\text { Nose } \\
\text { radius } \\
(\mathbf{m m})\end{array}$ & $\begin{array}{l}\text { Feed } \\
(\mathrm{mm} / \mathrm{rev} \\
)\end{array}$ & $\begin{array}{l}\text { Depth } \\
(\mathbf{m m})\end{array}$ & $\begin{array}{l}\text { Speed } \\
(\mathbf{m} / \mathbf{m i n})\end{array}$ \\
\hline \multirow{3}{*}{2} & \multirow{3}{*}{.2} & \multirow{3}{*}{.5} & 94 \\
\hline & & & 157 \\
\hline & & & 263 \\
\hline
\end{tabular}

Table 8. Nose radius parameters for the study of micro images of machined surface.

\begin{tabular}{|l|l|l|l|}
\hline $\begin{array}{l}\text { Speed } \\
(\mathbf{m} / \mathbf{m i n})\end{array}$ & $\begin{array}{l}\text { Feed } \\
(\mathbf{m m} / \mathbf{r e v})\end{array}$ & $\begin{array}{l}\text { Depth } \\
(\mathbf{m m})\end{array}$ & $\begin{array}{l}\text { Nose radius } \\
(\mathbf{m m})\end{array}$ \\
\hline & & & 2 \\
\cline { 3 - 4 } 94 & .2 & .5 & 3 \\
\cline { 3 - 4 } & & .5 \\
\hline
\end{tabular}

Table 9. Depth parameters for the study of micro images of machined surface.

\begin{tabular}{|l|l|l|l|}
\hline $\begin{array}{l}\text { Speed } \\
(\mathbf{m} / \mathbf{m i n})\end{array}$ & $\begin{array}{l}\text { Feed } \\
(\mathbf{m m} / \mathbf{r e v})\end{array}$ & $\begin{array}{l}\text { Nose } \\
\text { radius } \\
(\mathbf{m m})\end{array}$ & $\begin{array}{l}\text { Depth } \\
(\mathbf{m m})\end{array}$ \\
\hline \multirow{3}{*}{94} & .2 & 2 & .5 \\
\hline & & 1 \\
\hline & & 1.5 \\
\hline & & $\begin{array}{l}\text { Feed } \\
(\mathrm{mm} / \mathrm{rev} \\
\end{array}$ \\
& & & 0.05 \\
\hline & & 0.07 \\
\hline & & 0.1 \\
\hline & & & 0.15 \\
\hline
\end{tabular}

Table 10. Feed parameters for the study of micro images of machined surface.

\begin{tabular}{|l|l|l|l|}
\hline $\begin{array}{l}\text { Nose } \\
\text { radius } \\
(\mathbf{m m})\end{array}$ & $\begin{array}{l}\text { Speed } \\
(\mathbf{m} / \mathbf{m i n})\end{array}$ & $\begin{array}{l}\text { Depth } \\
(\mathbf{m m})\end{array}$ & $\begin{array}{l}\text { Feed } \\
(\mathbf{m m} / \mathbf{r e v})\end{array}$ \\
\hline & & & .05 \\
\cline { 3 - 4 } 2 & 94 & .5 & .1 \\
\cline { 3 - 4 } & & .15 \\
\hline
\end{tabular}

\section{RESULT AND DISCUSSIONS}

3.1 Influence of the cutting speed on the form of chip The cutting conditions are $\mathrm{f}=0.1 \mathrm{~mm} / \mathrm{rev}, \mathrm{d}=1 \mathrm{~mm}$, cutting speed varies from 55 to $263 \mathrm{~m} / \mathrm{min}$. The chips observed were all in serrated shapes, they are short and curled at low cutting speed, continuous chips at $55 \mathrm{~m} / \mathrm{min}$, elemental between 94 and $263 \mathrm{~m} / \mathrm{min}$, and reduced to paste at higher speeds. The chip types obtained at different speeds are shown in table 11 and the micro images of the chips as shown in fig 1. 
With the increase in speed the tooth flank starts getting wider. First the chip tooth forms uniform saw tooth as shown in figure 1 (b) and then the tooth becomes pointed and distorted as shown in figure 1(b) and 1(c). With further increase in speed the cracks occur on the tooth of the chip. With increasing speed the heat generation increases and due to these the temperature increases (chinchanikar, 2014). The increasing temperature changes the phase of microstructure and chips become ductile and further increase of speed turns into splitting of chip powder on the machined surface.

Table 11. Types of chip obtained at different cutting speed

\begin{tabular}{|c|l|}
\hline Speed (m/min) & Types of chip \\
\hline 55 & Continuous Chip \\
\hline 94 & Uniform saw tooth chip \\
\hline 157 & Non-uniform saw tooth chip \\
\hline 263 & Saw-tooth chip with broken tooth \\
\hline
\end{tabular}

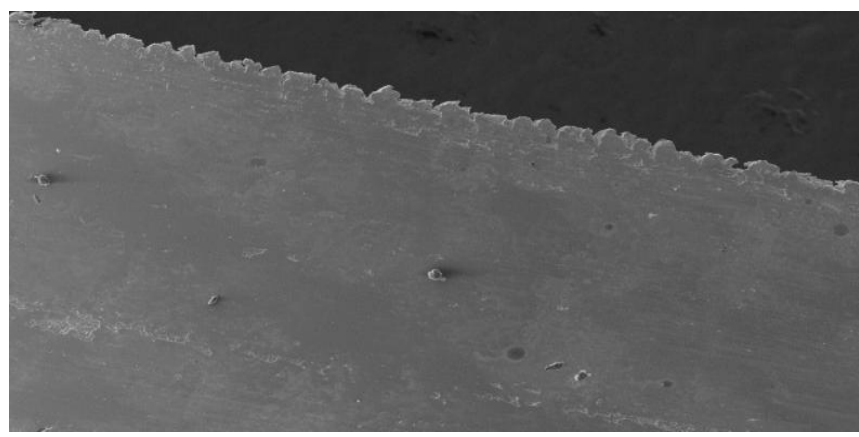

(a)

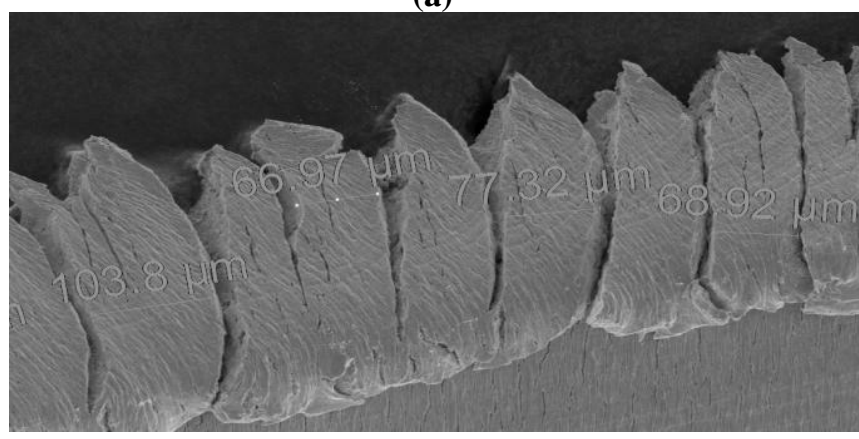

(B)

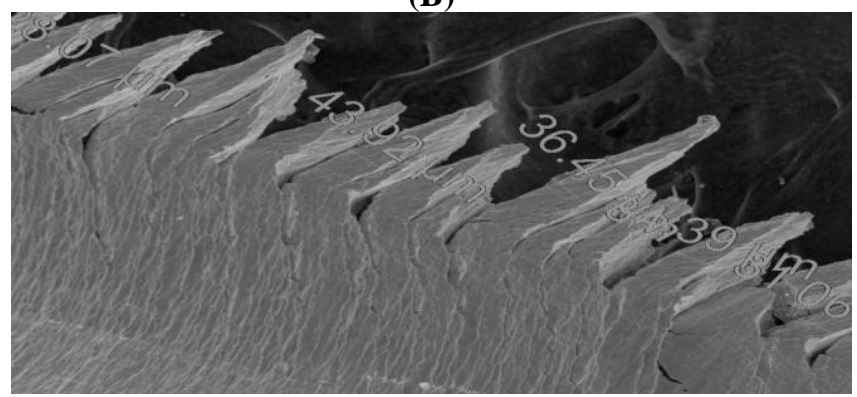

(C)

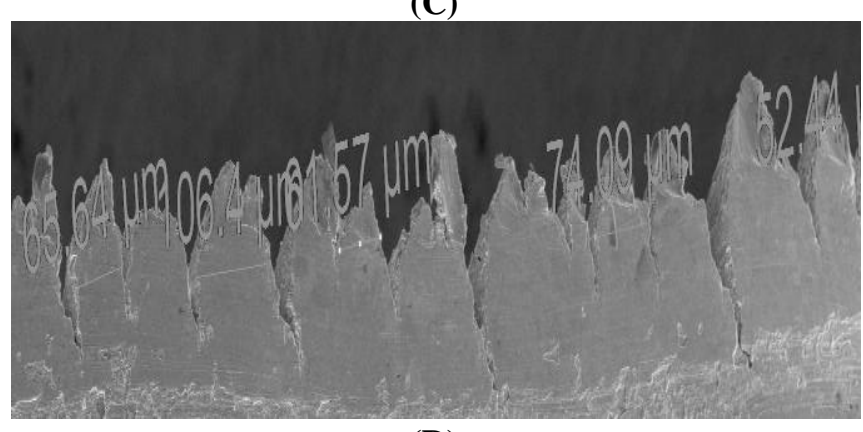

(D)
Figures 1 Chips at various cutting speeds and constant feed $.1 \mathrm{~mm} / \mathrm{rev}$ (a) Continuous Chip (v=55 m/min) (b) Saw tooth uniform chip (v=94 m/min) (c) Saw tooth non-uniform chip ( $\mathrm{v}=157 \mathrm{~m} / \mathrm{min}$ ) (d) Saw tooth chip with broken tooth (v=

$$
263 \mathrm{~m} / \mathrm{min} \text { ) }
$$

\subsection{Influence of the feed on the form of chip}

The cutting conditions are $\mathrm{V}=94 \mathrm{~m} / \mathrm{min}, \mathrm{d}=1 \mathrm{~mm}$, feed rate varies from 0.05 to $0.15 \mathrm{~mm} / \mathrm{rev}$. The chips are continuous chips at $\mathrm{f}=0.05 \mathrm{~mm} / \mathrm{rev}$ and above this rate, they become discontinuous, and if higher feed rates are applied then the chip s are reduced to paste or very small pieces. The chip types obtained at different feeds are shown in table 12 and the micro images of the chips as shown in fig 2 . At $.05 \mathrm{~mm} / \mathrm{rev}$ the chip has a continuous shape and as the feed is increased to $.07 \mathrm{~mm} / \mathrm{rev}$ the chip is slightly continuous and slightly saw-tooth and it means the chips are not completely saw-tooth and it can be named as wavy chips. At $.1 \mathrm{~mm} / \mathrm{rev}$ the chip takes the complete shape of saw-tooth and tooth flanks are also uniform. With further increase in feed the chip formation remains saw-tooth but the tooth flanks becomes wider and non-uniform.

Table 12. Types of chip obtained at constant speed

\begin{tabular}{|c|c|}
\hline Feed (mm/rev) & Types of chip \\
\hline .05 & Continuous chip \\
\hline .07 & Wavy chips \\
\hline .1 & Uniform Saw tooth chips \\
\hline .15 & Non- uniform saw tooth chip \\
\hline
\end{tabular}

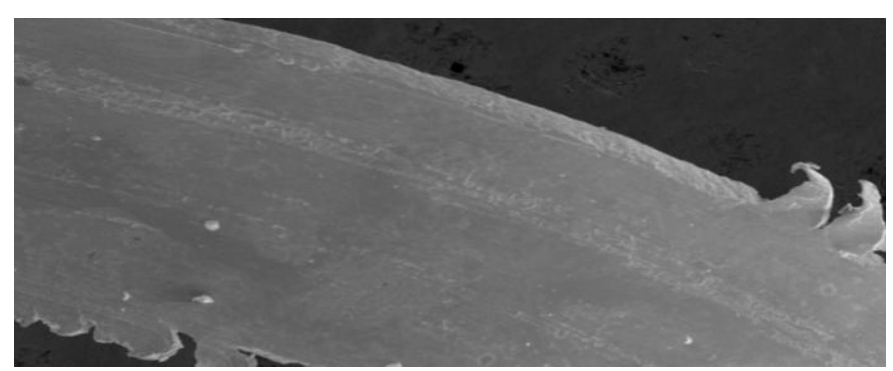

(a)

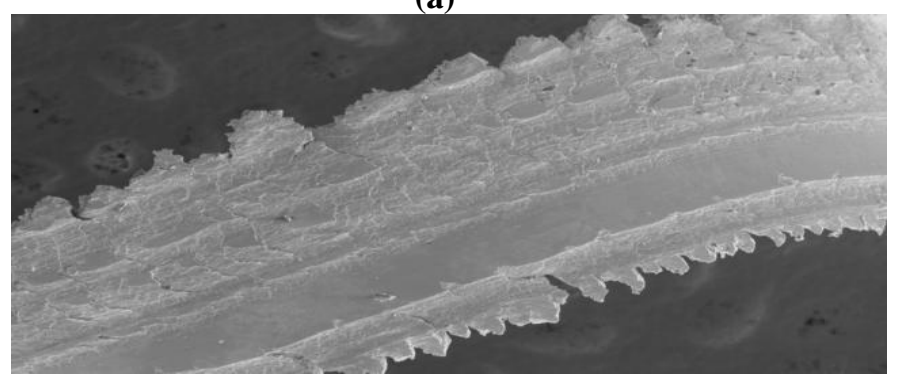

(b)

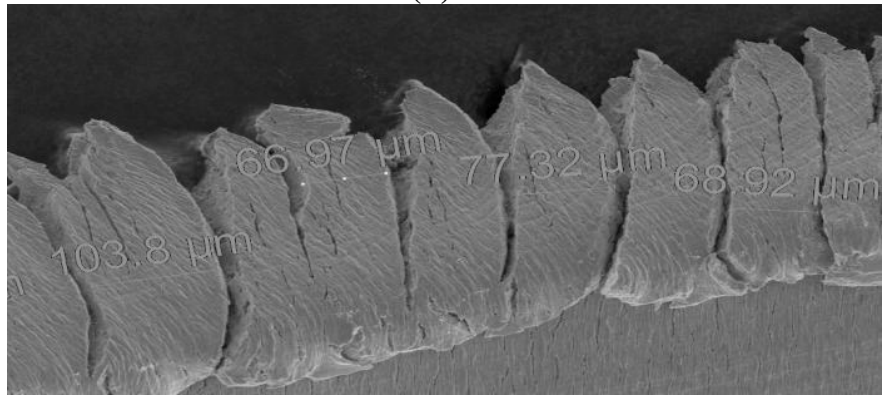

(C)

Published By: 


\section{Analysis of AISI D2 Steel by using SEM Images}

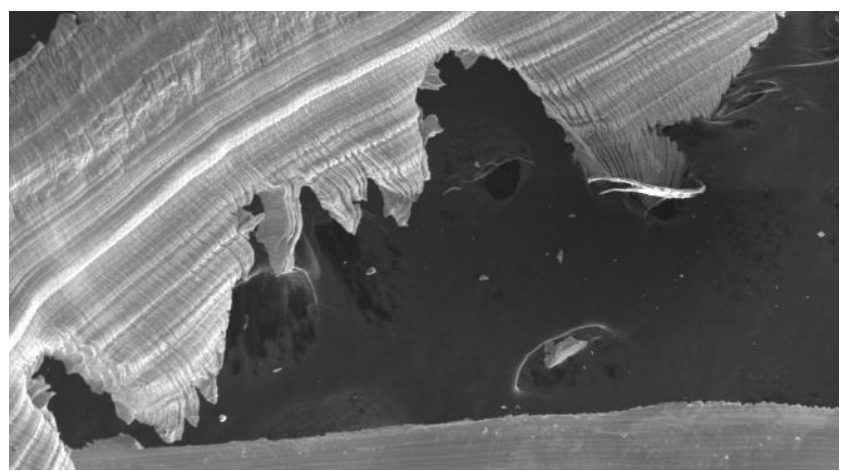

(d)

Figure 2 Chips at various feeds and constant speed $94 \mathrm{~m} / \mathrm{min}$ (a) Continuous chips (feed $=.05 \mathrm{~mm} / \mathrm{rev}$ ) (b) Wavy Chips (feed $=.07 \mathrm{~mm} / \mathrm{rev}$ ) (c) Uniform saw tooth chip (feed $=.1$ $\mathrm{mm} / \mathrm{rev}$ ) (d) Non uniform saw tooth chip (feed $=.15 \mathrm{~mm} / \mathrm{rev}$ )

Although the saw-tooth chip is formed with both increasing speed and increasing feed but increase in speed generates saw tooth more quickly than increasing feed and the increasing speed involves non- uniform and distorted tooth flanks and increasing feed involves uniform and less distorted tooth flanks.

\subsection{Surface and sub-surface deformation and white layer formation}

Experiments were conducted to study the surface micro-structure with a view to examine the SEM images surface and sub-surface cracks and white layer formation. The experiments were done at done at different combination of parameters. The results are discussed as follows:

\section{(a) Case 1 - Increasing Nose radius}

The experiments were done at a feed $=.2 \mathrm{~mm}$, speed $=94$ $\mathrm{m} / \mathrm{min}$, depth $=.5 \mathrm{~mm}$ and with increasing nose radius from 2, 3 and $5 \mathrm{~mm}$.

(1) Nose radius $=2 \mathrm{~mm}$, feed $=.2 \mathrm{~mm} / \mathrm{rev}$, speed $=94 \mathrm{~m} /$ min, depth $=.5 \mathrm{~mm}$

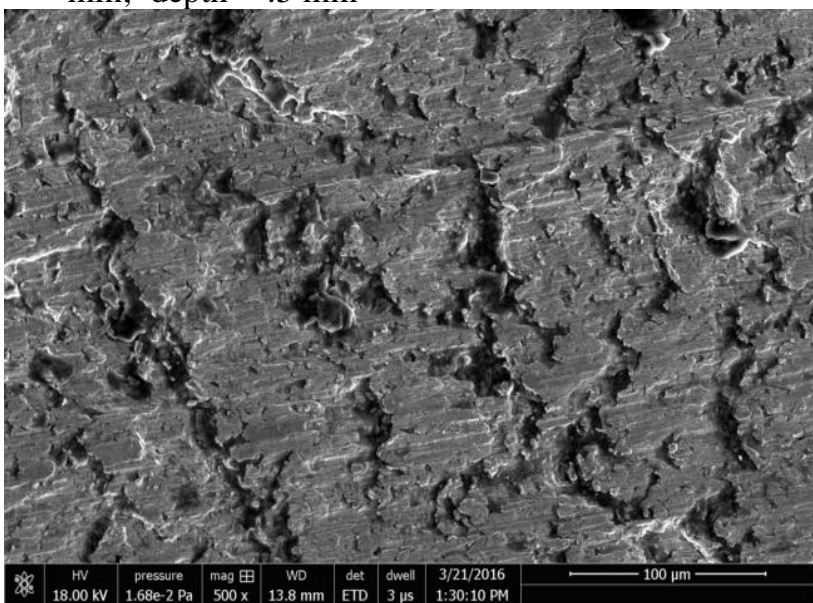

Micro-cracks Figure - 3(a)) Micro images of machined surface at Nose radius $=2 \mathrm{~mm}$, speed $=94 \mathrm{~m} / \mathrm{min}$, feed, $=.2 \mathrm{~mm}$, Depth $=.5 \mathrm{~mm}$

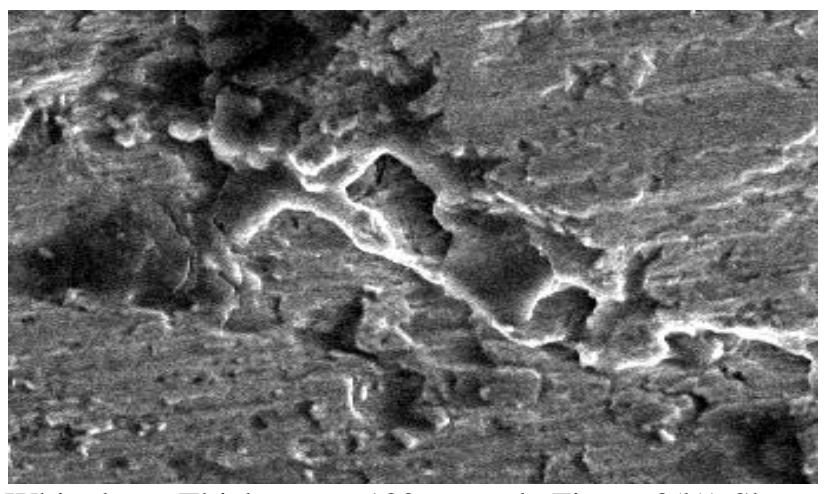

White layer Thickness at $100 \mu \mathrm{m}$ scale Figure 3(b)) Shows the white layer thickness at Nose radius $=2 \mathrm{~mm}$, speed $=94 \mathrm{~m} / \mathrm{min}$, feed $=.2 \mathrm{~mm}$, Depth $=.5 \mathrm{~mm}$

The figure 3(a) clearly depicts sub-surface and surface defects i.e. micro-cracks and cavities, here at this cutting condition the density of cracks and cavities are very large and the figure 3(b) shows the widening of white layer formation which is about $2 \mu \mathrm{m}$. Cutting tool has a nose radius of $2 \mathrm{~mm}$ which provides a sharp cutting edge which leads to the formation of more cavities and cracks and larger white layer thickness. Due to micro-structural changes, the lengths of the cracks are varying from minimum $12.99 \mu \mathrm{m}$ to a maximum of $19.28 \mu \mathrm{m}$.

(2) Nose radius $=3 \mathrm{~mm}$, feed $=.2 \mathrm{~mm} / \mathrm{rev}$, speed $=94 \mathrm{~m} / \mathrm{min}$, depth $=.5 \mathrm{~mm}$

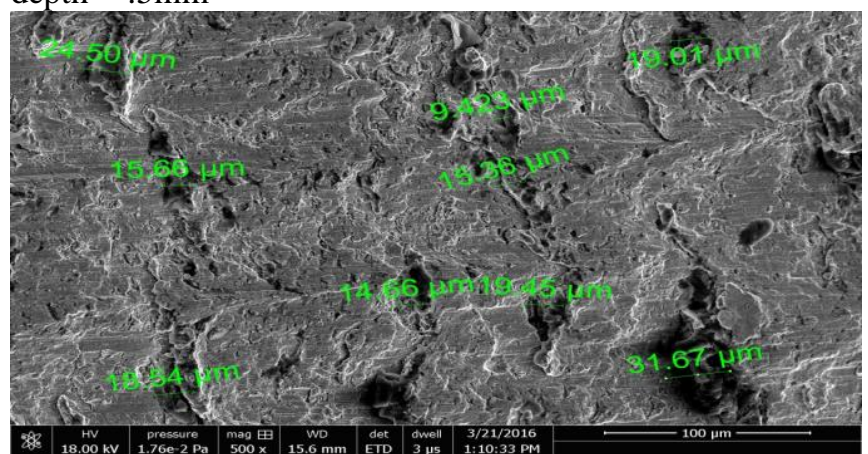

Figure 3(c)) Shows the length of various cracks at Nose radius $=3 \mathrm{~mm}$, speed $=94 \mathrm{~m} / \mathrm{min}$, feed, $=.2 \mathrm{~mm}$, Depth $=.5$

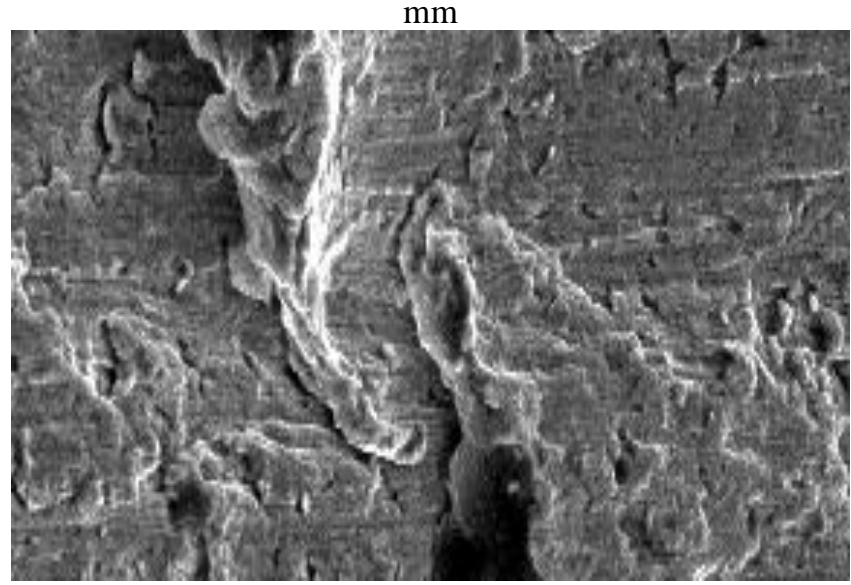

White layer Thickness at $100 \mu \mathrm{m}$ scale Figure 3(d) Shows the white layer thickness at Nose radius $=3 \mathrm{~mm}$, speed $=94 \mathrm{~m} / \mathrm{min}$, feed, $=.2 \mathrm{~mm}$, Depth $=.5 \mathrm{~mm}$

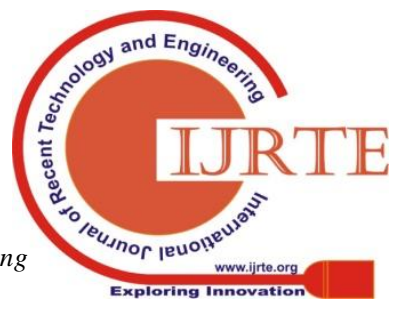


With the increasing in nose radius at constant feed, speed, depth respectively the density of cracks and cavities becomes less and also the thickness of white layer becomes less as shown in figure $3(\mathrm{~d})$ which is about $1.8 \mu \mathrm{m}$. Although the length of the cracks are varying from minimum of $9.4 \mu \mathrm{m}$ to maximum of $31.67 \mu \mathrm{m}$ but the cracks are almost half as compared to previous case.

Here in this case the cutting tool has a nose radius of $3 \mathrm{~mm}$ which has a relatively less sharper edge than $2 \mathrm{~mm}$ tool and speed, feed, depth are remain constant. Hence increasing nose radius improves the fatigue life of work piece surface.

(3) Nose Radius $=5 \mathrm{~mm}$, feed $=.2 \mathrm{~mm} / \mathrm{rev}$, speed $=94$ $\mathrm{m} / \mathrm{min}$, depth $=.5 \mathrm{~mm}$

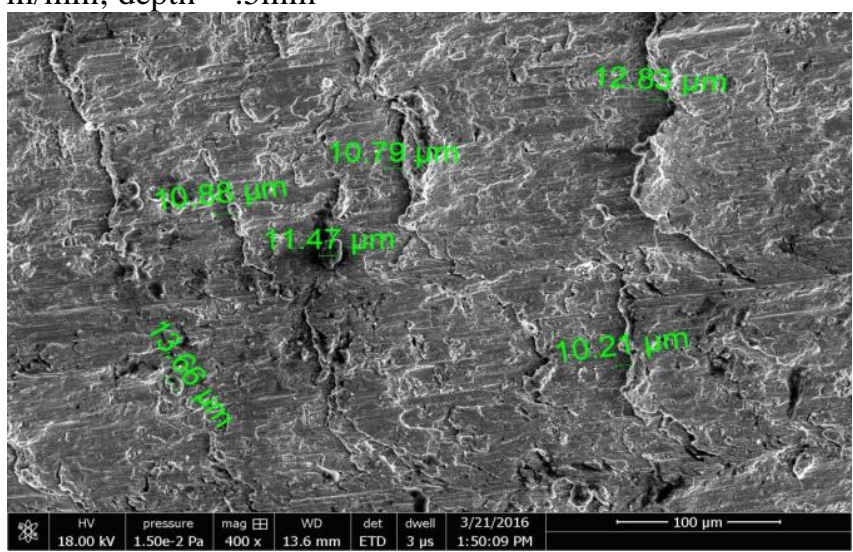

Figure 4.(a) Shows the length of various cracks at Nose radius $=5 \mathrm{~mm}$, speed $=94 \mathrm{~m} / \mathrm{min}$, feed, $=.2 \mathrm{~mm}$, Depth $=.5$

$\mathrm{mm}$

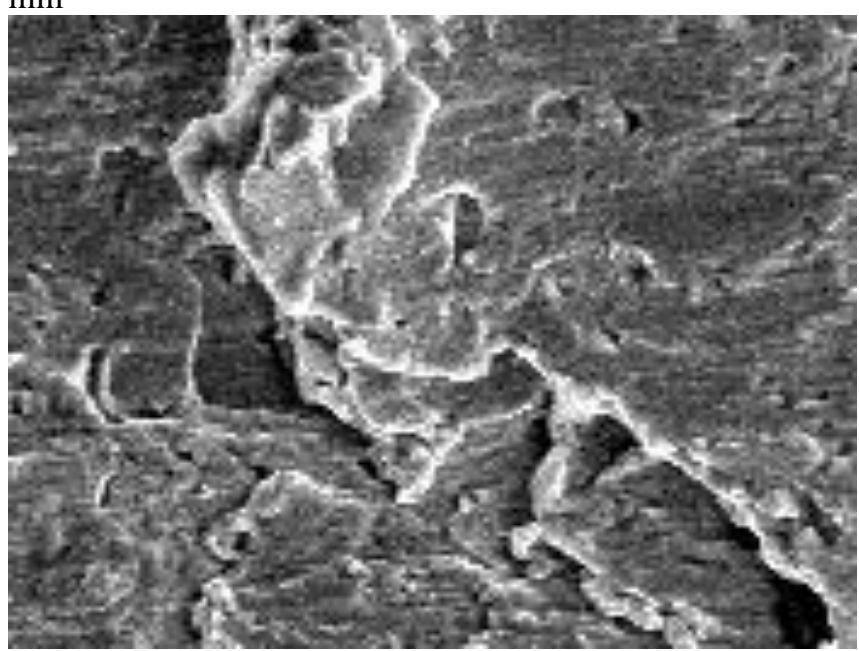

White layer Thickness at $100 \mu \mathrm{m}$ scale

Figure 4(b) Shows the white layer thickness at Nose radius= $5 \mathrm{~mm}$, speed $=94 \mathrm{~m} / \mathrm{min}$, feed, $=.2 \mathrm{~mm}$, Depth $=.5 \mathrm{~mm}$

As shown in figure 4(a), 4(b) the micro-cracks and cavities becomes less and white layer formation thickness also reduces with increasing nose radius. Therefore tool with large nose radius can be favorable for cutting conditions. The lengths of the cracks are varying from minimum of $10.24 \mu \mathrm{m}$ to $13.66 \mu \mathrm{m}$ which is much less than with the nose radius of $2 \mathrm{~mm}, 3 \mathrm{~mm}$ respectively.

Micro cracks, cavity, and white layer formation relates to the fatigue life and surface quality of machine components. Here the tool has a nose radius of $5 \mathrm{~mm}$ which provides round cutting edge which leads to decrease in the density of cracks and cavities as shown in figure 4(a) White layer thickness also reduces to $1.75 \mu \mathrm{m}$ and hence fatigue life and surface quality of machined work piece improves with increase in nose radius.

\section{Case 2- Increasing speed}

(4) Nose radius $=2 \mathrm{~mm}$, feed $=.2 \mathrm{~mm}$, speed $=157 \mathrm{~m} / \mathrm{min}$, depth $=.5 \mathrm{~mm}$

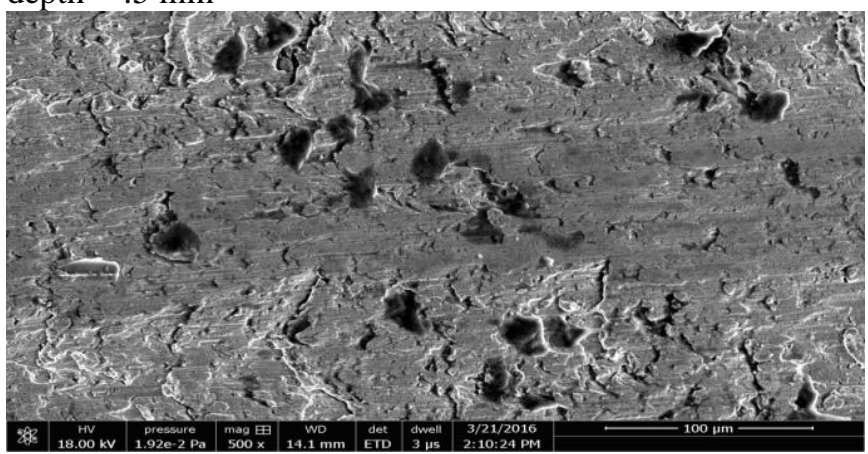

Figure 5(a)Micro images of machined surface at Nose radius $=2 \mathrm{~mm}$, feed $=.2 \mathrm{~mm}$, speed $=157 \mathrm{~m} / \mathrm{min}$, depth $=.5 \mathrm{~mm}$

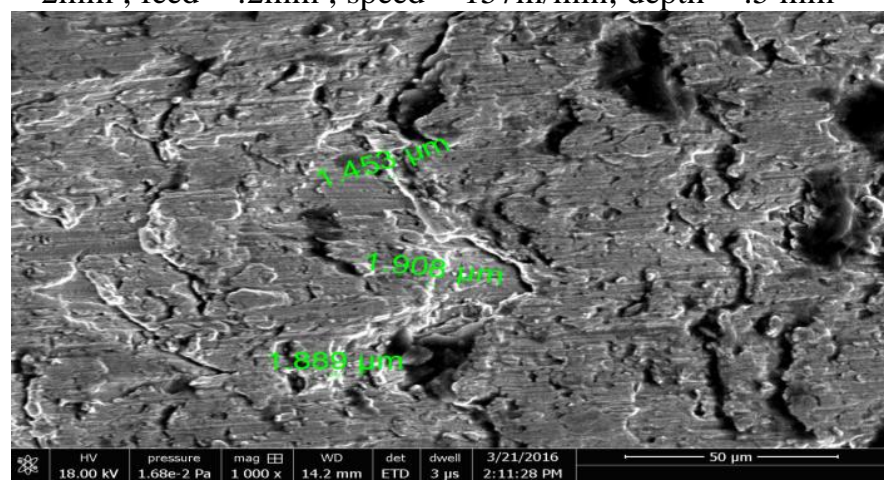

White layer Thickness

Figure 5(b) Shows the white layer thickness at Nose radius $=$ $2 \mathrm{~mm}$, feed $=.2 \mathrm{~mm}$, speed $=157 \mathrm{~m} / \mathrm{min}$, depth $=.5 \mathrm{~mm}$

With the increase in speed the temperature increases and hence the decomposition of carbide particles is observed. Due to increase in temperature the microstructure changes and transition in phase occurs from austenite to martensite phase. Although the cracks are less but due to large density of deformed carbide particles the surface quality reduces. From fig 5(b) the white layer thickness $(1.90 \mu \mathrm{m})$ also relatively increase which reduces the fatigue life. The cracks are although less but are much bigger i.e. $23.30 \mu \mathrm{m}$ as shown in figure 5(a) which also reduces the fatigue life.

(5) Nose radius $=2 \mathrm{~mm}$, feed $=.2 \mathrm{~mm} / \mathrm{rev}$, speed $=263$ $\mathrm{m} / \mathrm{min}$, depth $=.5 \mathrm{~mm}$

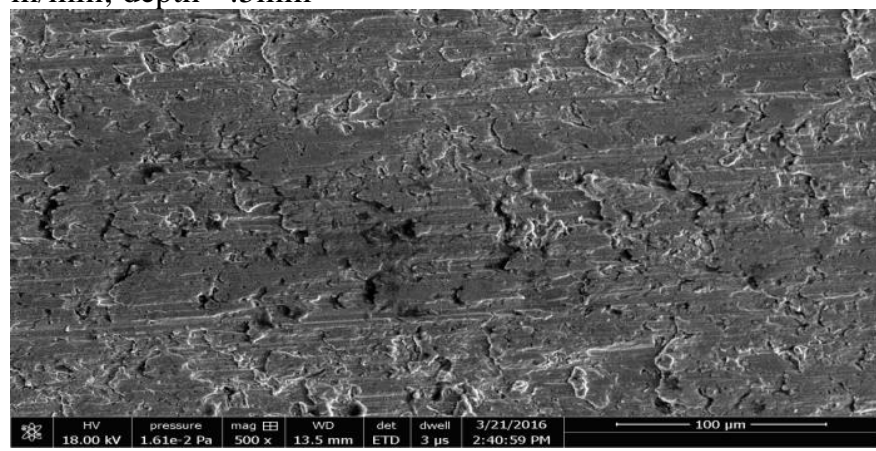

Figure 6(a) Micro images of machined surface at Nose radius $=2 \mathrm{~mm}$, feed $=.2 \mathrm{~mm} / \mathrm{rev}$, speed $=263 \mathrm{~m} / \mathrm{min}$, depth $=.5 \mathrm{~mm}$

\section{Published By:}

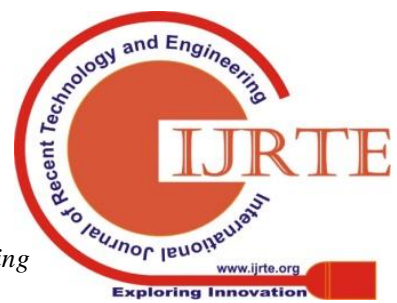




\section{Analysis of AISI D2 Steel by using SEM Images}

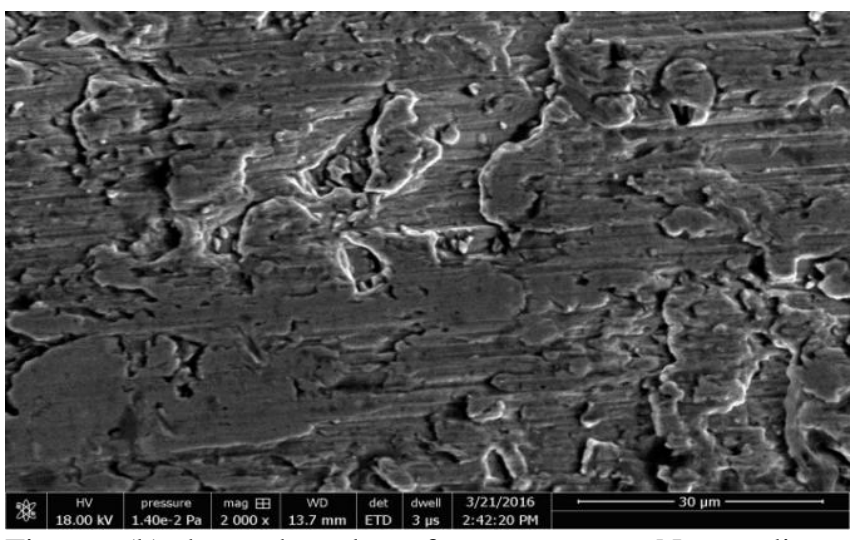

Figure 6(b) shows the sub-surface structure at Nose radius $=$ $2 \mathrm{~mm}$, feed $=.2 \mathrm{~mm}$, speed $=263 \mathrm{~m} / \mathrm{min}$, depth $=.5 \mathrm{~mm}$

The white layer formation thickness increases as shown in figure 6(b) and that is about $3.5 \mu \mathrm{m}$ and $3.7 \mu \mathrm{m}$. Although micro cracks occur at low as well as high cutting speed but the density of these micro cracks is less at a higher cutting speed. It is observed that the lower density of surface micro cracks at an increasing cutting speed is associated with increase in temperature of cutting which causes softening and ductile nature in the surface and surface underneath. Figure 6(a) reveal the sub-surface structure where large carbide is forced to deform in the vicinity of the surface due to local ductility caused by cutting temperature and pressure. However, lower deformability of carbide particle cause micro cracks beneath the machined surface where the effect of cutting temperature diminishes.

\section{Case 3: Increasing depth}

(6) Nose radius $=2 \mathrm{~mm}$, feed $=.2 \mathrm{~mm} / \mathrm{rev}$, speed $=94 \mathrm{~m} / \mathrm{min}$, depth $=1 \mathrm{~mm}$

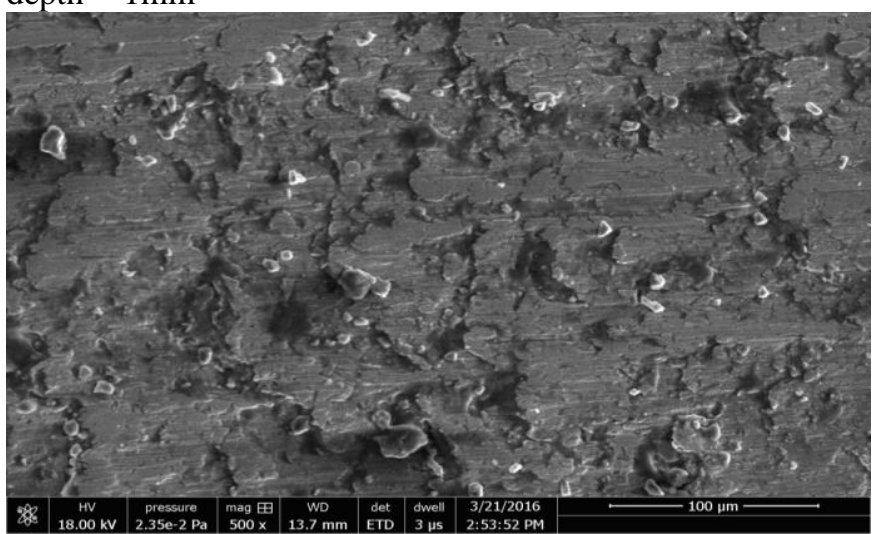

Figure 7(a) Micro images of machined surface at Nose radius $=5 \mathrm{~mm}$, feed $=.2 \mathrm{~mm} / \mathrm{rev}$, speed $=94 \mathrm{~m} / \mathrm{min}$, depth $=1 \mathrm{~mm}$

As discussed, the chip particles break way heavily with the increase in depth and start adhering to the machined surface. As shown in figure 7(a) large adhered chip particles which is the result of hardness of chip. As depth of cut involves more removal of material thus the chip becomes brittle and harder. Chip particles are sharp and they collide with the surface at a fast pace which can also reduces the surface quality. The micro-cracks are small and the volume of the cracks are also less and white layer formation is almost absent and white layer formation is the result of high temperature deposition and in case of increasing depth the temperature does not increase more than increase in speed. But the chip particle also affects surface quality and fatigue life.
(7) Nose radius $=2 \mathrm{~mm}$, feed $=.2 \mathrm{~mm}$, speed $=94 \mathrm{~m} / \mathrm{min}$, depth $=1.5 \mathrm{~mm}$

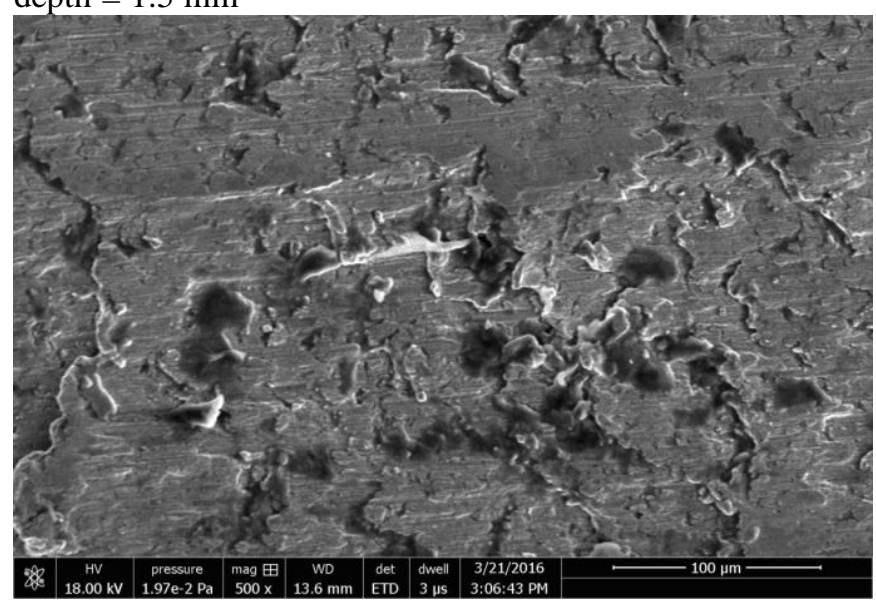

Figure 8(a) Micro images of machined surface at Nose radius $=2 \mathrm{~mm}$, feed $=.2 \mathrm{~mm} / \mathrm{rev}$, speed $=94 \mathrm{~m} / \mathrm{min}$, depth $=$ $1.5 \mathrm{~mm}$

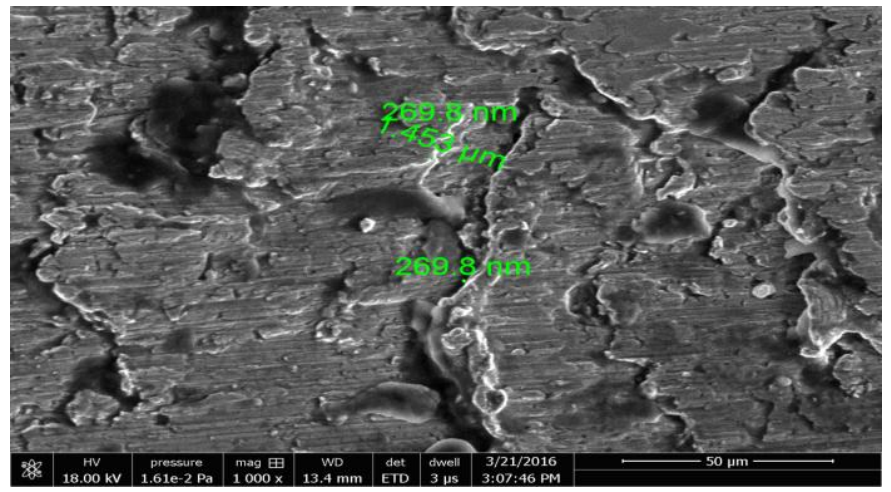

Figure 8(b) Shows the white layer thickness at Nose radius $=$ $2 \mathrm{~mm}$, feed $=.2 \mathrm{~mm} / \mathrm{rev}$, speed $=94 \mathrm{~m} / \mathrm{min}$, depth $=1.5 \mathrm{~mm}$

Figure 8(b) reveal that with further increase in depth the white layer formation thickness decreases i.e. the white layer thickness is about $269.8 \mathrm{~nm}$ and $1.4 \mu \mathrm{m}$ which are way lesser than comparison to increase in speed but the density of chip particles increases with increase in depth.

\section{Case 4: Increasing feed}

(7) Nose radius $=2 \mathrm{~mm}$, feed $=.4 \mathrm{~mm} / \mathrm{min}$, speed $=94$ $\mathrm{m} / \mathrm{min}$, Depth $=1 \mathrm{~mm}$

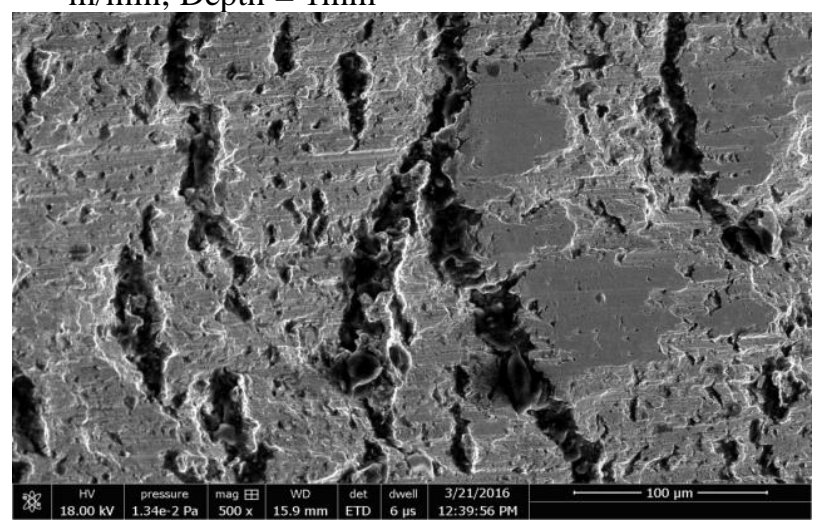

Micro-cracks Figure 9(a) Micro images of machined surface at Nose radius $=2 \mathrm{~mm}$, feed $=.4 \mathrm{~mm} / \mathrm{rev}, \quad$ speed $=94 \mathrm{~m} / \mathrm{min}$, depth $=1 \mathrm{~mm}$

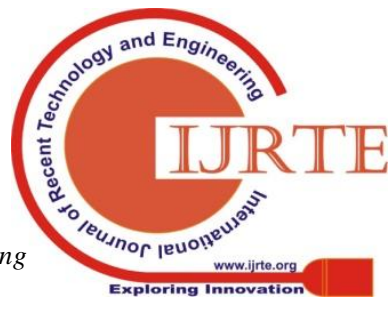




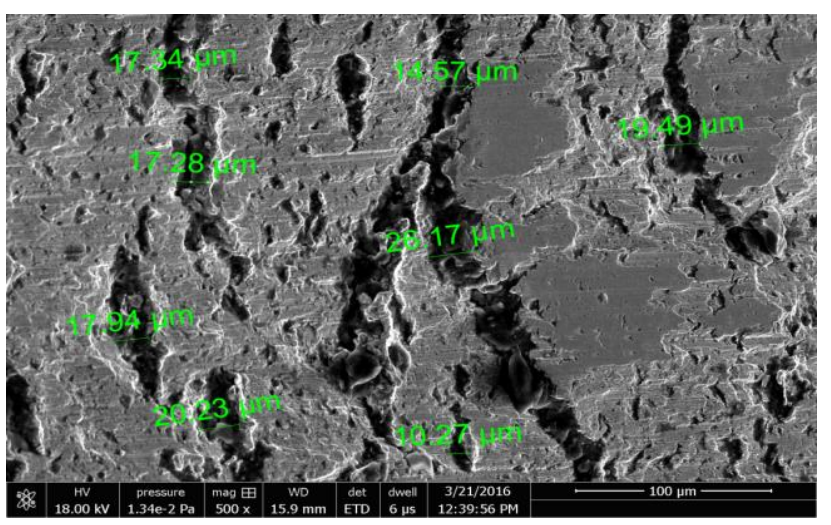

Figure 9(b) Shows the length of various cracks at Nose radius $=2 \mathrm{~mm}$, feed $=.4 \mathrm{~mm} / \mathrm{rev}$, speed $=94 \mathrm{~m} / \mathrm{min}$, depth $=1 \mathrm{~mm}$ (9) Nose radius $=2 \mathrm{~mm}$, feed $=. .75 \mathrm{~mm} / \mathrm{rev}$, speed $=94$ $\mathrm{m} / \mathrm{min}$, Depth $=1 \mathrm{~mm}$

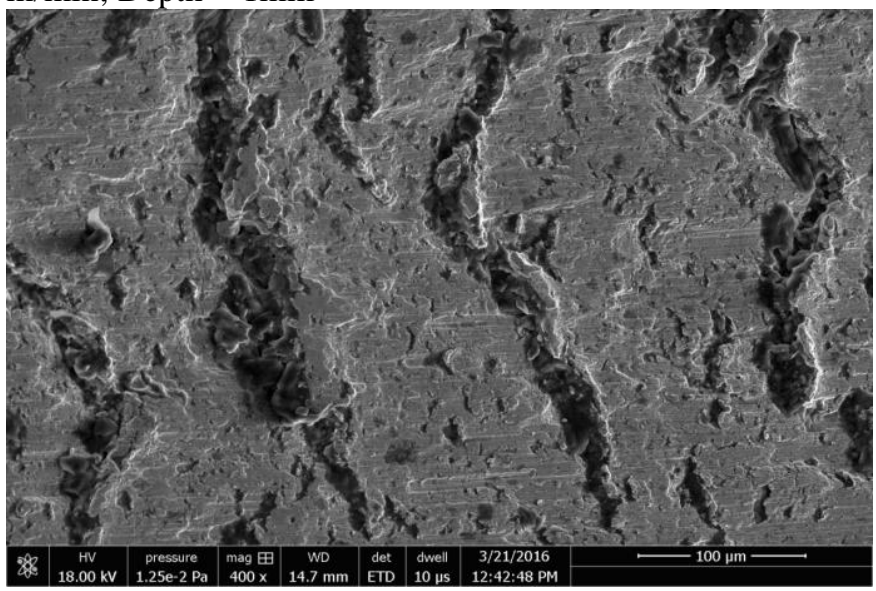

Figure 10 (a) Shows the length of various cracks Nose radius $=2 \mathrm{~mm}$, feed $=.75 \mathrm{~mm} / \mathrm{rev}$, speed $=94 \mathrm{~m} / \mathrm{min}$, Depth $=1 \mathrm{~mm}$

Figure 9(a).9(b), 10(a) reveal that with increase in feed the cracks become long and wide i.e. it varies from minimum of $20 \mu \mathrm{m}$ to maximum of $32 \mu \mathrm{m}$ which is higher than other cutting conditions. White layer formation thickness is lesser than depth, speed and nose radius and the adhered chip particles density is almost negligible. The main source of surface micro cracks is work piece material non homogeneity caused by local differences in the material element concentration and as well as the existence of chromium carbide particles. Although micro cracks occurs in all the cutting conditions but density of these micro-cracks is less with increasing speed as comparison to increase in feed and depth. To a greater extent, these damages influence the performance of product. Micro-cracks existing on the surface produced reduced the fatigue resistance of the product. White layer formation and thickness decreases with increase in nose radius and increases with increase in cutting speed, while it is less with increase in feed and depth of cut. White layer thickness which is supposed to be a result of temperature created on the surface of work piece and with increase in speed the temperature becomes highest .From all these discussions this is concluded that increasing speed can cause poor surface quality and reduces fatigue life and this is followed by depth and then feed.
The main conclusions from the present work are as follows. 2 Saw tooth are formed with increasing feed, speed, and depth of cut.

3 With increasing speed the chip tooth flank becomes distorted and non-uniform and increasing feed also produces saw-tooth chip but the chip has uniform tooth flank and less distorted.

5 Cutting tool with increasing nose radius produces less micro-cracks and white layer formation with less thickness on machined surface.

6 Increasing speed involves carbide decomposition and white layer formation with larger thickness on machined surface which results because of change in the phase of machined surface and increasing depth involves detachment of chip particles and it affects the machined surface and increasing feed produces wider cracks. Hence increasing speed has highest effect on surface quality of machined surface followed by increasing speed, depth, feed and nose radius.

\section{SUGGESTIONS FOR FUTURE WORK}

It is suggested that future work in this area can be directed towards the following:

1 The chip segmentation model can be developed. Thus, the force fluctuation can be determined analytically, and consequently, this would help in studying the cutting tool life.

2 Surface roughness for hard turning can also be measured which gives more clear idea of hard turning.

3 Different cutting tools study can also be done to the best suited cutting for hard turning.

\section{REFERENCES}

1. Molinari, C. Musquar and G. Sutter,(2002) Adiabatic shear banding in high speed machining of Ti-6Al-4V: experiments and modeling, International journal of Plasticity, 18: 443-459.

2. G. Sutter,(2005) Chip geometries during high-speed machining for orthogonal cutting conditions, International Journal of MachinesTools \&Manufacture, 45 :719-726.

3. Hortig and B. Svendsen, (2007) Simulation of chip formation during high-speed cutting, Journal of Materials ProcessingTechnology, 186:66-77

4. R. Komanduri and R. H. Brown,(1981) the mechanics of chip segmentation in machining, Journal of Engineering for Industry, 103: 33-51.

5. R. Komanduri, T. Schroeder, B. F VonTurkovitch and O. G. Flom, (1982) On the catastrophic shear instability in high speed machining of an AISI 4340 steel, ASME Transaction-Journal ofEngineering for Industry, 104: 121-131.

6. W. Konig, (1990) Machining hard materials with geometrically defined cutting edges-Filed of applications and limitations, Annals of CIRP, 39 :413-425.

7. M. Shaw, (1998) The mechanism of chip formation with hard turning steel, Annals of the CIRP, $39: 77-82$.

8. R. Recht,(1964) Catastrophic thermoplastic shear,Journal of Applied Mechanics, $31: 189-193$

9. (9) R. Recht,,(1985) A dynamic analysis of high speed machiningASME Transaction-Journal of Engineering for Industry, 107: 309-315.

10. G. Poulachon, A. Moisan and M. Dessoly, Contribution (2002) àl'étude des mécanismes de coupe en tournagedur, Mécanique\& Industries, 3 . 291-299.

\section{CONCLUSIONS}




\section{AUTHOR PROFILE}

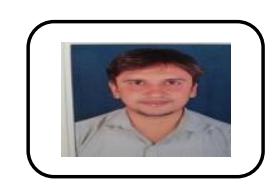

Shambhu P. Choubisa, Assistant Professor,

Mechanical Engineering Department, Techno India

NJR Institute of Technology, Udaipur (India).

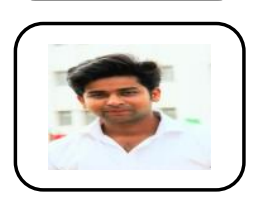

Abhishek Sharma, Assistant Professor, Mechanical Engineering Department, Techno India NJR Institute of Technology, Udaipur (India).

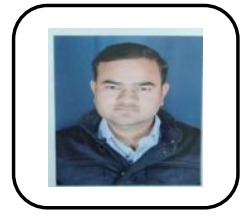

Himanshu Pandya, Assistant Professor, Mechanical Engineering Department, Techno India NJR Institute of Technology, Udaipur (India). 